\title{
Reconstructing the Iraqi Political System The Post-Saddam Era: The Role of the United States and the Coalition Forces
}

\author{
Abdul Wahed Jalal Nori \\ Institute of Strategic \& International Studies-Malaysia \\ Bangunan Institiut Antara Bangsa, Jalan Parlimen, 50480 \\ Tel: (603)26915435 / HP: 01123877764 \\ Submitted: 24 September 2015, Accepted: 15 October 2015
}

Most of the works that have been published on the post-Saddam political system deal with the role of US in the process of state building efforts and peace implementation in post-Saddam politics. However, the contribution of the domestic political elites in this transitional period of democratic consolidation has been, to a large extent, neglected by scholars in general and those in political science, in particular. Yet, there exists a considerable scholarly literature examining the functioning of the political system in the post-Saddam era. These can be divided into three categories:

1) Works dealing with the role of the US;

2) Studies dealing with the country's constitutional arrangements and the nature of the political system, its advantages and disadvantages;

3) Literature dealing with applicability of different forms of power-sharing arrangements such as federalism, consociational and integrative approaches.

\section{THE ROLE OF THE US:}

Works related to the role of the U.S. in establishing and making the Iraqi political system functions properly are quite numerous. Liam Anderson and Gareth Stanfield survey a broader field, the overall future of Iraq and what is most more likely to become of its "democracy dilemma," that is the magnitude of the task confronting the United States of America in post-Saddam Iraq (Stanfield, 2004). They clearly conclude that a managed partition by the U.S. and therefore independence for the Kurds is the least worse option: "on balance, an independent Kurdistan resolves more problems than it creates." (Stanfield, 2004, p. 217) However, they are pessimistic about the ability of United States to achieve its stated goal of democratizing Iraq while preserving its territorial integrity as a state, (Stanfield, 2004, p. 224) for several reasons. In the first place, they note that "at the most fundamental level, democracy requires the existence of an implicit consensus on the legitimacy of the underlying order. It is questionable whether the Kurds have ever fully accepted the legitimacy of an Iraqi state that includes them within its borders. Second, any form of democracy requires trust, which has been pitifully absent in Iraq" (Stanfield, 2004, p. 10). Iraq "was an artificial British creation," (Stanfield, 2004, p. 186) which has only been able to be held together by the glue of authoritarianism. (Stanfield, 2004, p. 198) The minimum requirement for the successful reintegration of the Kurds into the state of Iraq is, therefore, a postSaddam political order characterized by pluralism, cultural tolerance, and a high degree of regional autonomy, precisely the sort of government that Iraq has never enjoyed. Moreover, the fact that Iraqi 
Kurdistan (in effect) has been independent since 1991 and operating separately from Baghdad has, in fact, created structural problems that would make it painful for Kurdistan to return to its pre-1991 position (Stanfield, 2004, p. 114). This split in the administration arrangement of the Iraqi state is arguably the most significant event in the country's modern history. Furthermore, democracy in Iraq would most likely result as it did, in majority Shi'a rule, which would not only overturn Sunni rule of Iraq since the creation of the state in the 1920s, but be a reversal of the historic Sunni victory during Islam's first century. As the current insurgency demonstrates, the Sunnis will not easily submit to Shi'a rule. After weighing this myriad of obstacles to a unified and democratic Iraq, Anderson and Stanfield conclude that the least worst outcome would be a managed partition in which the Kurds secede while the remaining Arab-populated units stay together (Stanfield, 2004, p. 216). Leslie Gelb and Peter Galbraith agree with Anderson and Stanfield and argued further that Iraq has "three distinct and sectarian communities," Sunni, Shia, and Kurd (Gelb L. H., 2004) (Galbraith, 2004). These communities, it is claimed, are largely geographically homogeneous and mutually hostile. They have been locked in an artificial, Sunni-dominated state for eighty-five years. This analysis leads its promoters to view the post-Saddam politics as tragic but that tragedy is largely unavoidable. This approach asserts that Iraqi politics has always been and will continue to be animated by deeply held communal antipathies. From this perspective, there can only be one policy option for the United States: the situation will be stabilized by dividing the country into three smaller, ethnically purer and more manageable units. There is a possibility that this could be done through a form of drastic decentralization, as proposed by U.S. senator Joseph R. Biden and Leslie Gelb. But this position argued consistently for its complete division into separate states (Gelb, 1 May 2006). However, Gelb and Galbraith argument of simply dividing Iraq into three ethnically purer states misses the main characteristic of
post-Saddam politics, which is the lack of institutional and coercive state capacity in Iraq. The radical decentralization of political power runs the distinct danger of devolving the violent struggle for supremacy. As Toby Dodge argued, this could localize the conflict among Shia groups and between the two main Kurdish political parties (KDP_PUK) (Toby Dodge, State Collapse and the Rise of Identity Politics in (Rowsweel, 2007)). What Iraq desperately needs is one coherent and functioning state, not three. Its governing institutions, bureaucratic, military, and political, must be rebuilt from the ground up across the territorial extent of the country (Rowsweel, 2007). Moreover, to make inroads Dodge argued that, the United States, the United Nations and the European Union need to present the Iraqi government with specific demands for good governance and reduction of the scope for corruption, patronage, and abuse in return for further aid and assistance (Rowsweel, 2007, p. 35). Therefore, the growth of stable state institutions, with a meaningful presence in people's lives, forms the framework within which the longer-term goal of successful state building, the reconstruction of an Iraqi nation, can be achieved (Rowsweel, 2007). Yahia Said agrees with Dodge and is very critical of U.S. policy in Iraq. He argues that the US-led coalition came to Iraq with a superficial groupist, preimordialists, atavistic reading of the country, one which downplayed the crosscutting ties that bound Iraqis together. The coalition provided an advantage to sectarian and ethnocentric leaders, and the descent into civil war began. These leaders then negotiated a sectarian and unfair constitution, which has further polarized matters (Said, 2006). Said accordingly, stresses the commonalities that Iraqis share and argue for nation building. He calls for a strong, centralized, and ethnically impartial Iraqi state. The Center for Arab Unity Studies (seated in Beirut, Lebanon) had already organized a major Seminar about the Occupation of Iraq and its repercussions on the Arab, Regional and International Scenes during 8-11 March 2004. Before, in the course and after that seminar, eight books (in Arabic) (Haseeb K. E.-D., 2004) (The Centre of Arab 
Unity Studies, 2004) (The Centre of Arab Unity, 2004) (Haseeb K. E.-D., 2006) were published by the Center on the same subject since the occupation of Baghdad (www.caus.org). In addition, about twentyfive issues of its monthly journal concentrated a big deal on the same subject. The Center regards the occupation of Iraq as apart of an American plan to redraw the map of the region with only the American objectives in view (www.caus.org). Therefore, what happens in Iraq influences, and will continue to influence, not only Iraq, but also the entire Arab region; indeed it will even have critical consequences and repercussions for the regional and international scenes. Whereas the Center is convinced that the occupation of Iraq will give rise to Arab, regional, and international turbulence and instability that will influence, positively or negatively, for a long term of time, the future of the Arab nation, therefore, the Center feels strongly, that it is obliged, as a matter of priority, to devote to the subject the energy and efforts it deserves.

\section{ON POWER SHARING}

John McGarry is one of the rare scholars who have tried to apply the theory of consociational democracy to the Iraqi political system in the post-Saddam era (McGarry). He discusses the impact of the theoretical debate on democratization in Iraq. He points to the general position that democratization requires more than merely free and fair elections and as such, the primary task for outsiders is to work with Iraq's democratically elected politicians and to support the internally negotiated constitution, while recommending and offering advice on constructive changes within the process for constitutional amendments, in order to create sustainable democratic development.

McGarry discusses two dominant approaches which have been offered for stopping Iraq's conflict and consolidating a democratic system there. The first approach is represented by the Integrationists who see post-Saddam Iraq as based on sectarian and ethnocentrism, usually seen as of recent origin, rather than rooted in age-old hatreds. They also stress the com- monalities that Iraqis share; therefore, they call for a strong, centralised and ethnically impartial Iraqi state (McGarry, p. 169). McGrry argued in favour of the second approach which focuses on the accommodation of Iraq's different communities (It is Consociationalism), simply because Iraq's new constitution is consistent with consociationalism (McGarry, p. 170). Therefore, he argued that the outsiders should work with Iraq's democratically elected politicians and support the internally negotiated constitution, while recommending and offering advice on constructive changes within the process for constitutional amendments, in order to create sustainable democratic development (McGarry, p. 184). Apart from that he further suggests that the international community should assist in building the "capacity" of regional (and governorate) government, and not just the capacity of the federal government, as integrationists recommend (McGarry).

Noah Feldman, a legal scholar and expert on constitutional law at New York University, served as Senior Constitutional Advisor to the CPA in Baghdad in 2003. From his high-level advisory position and through his public commentary since leaving Baghdad, Feldman has exerted a significant sway in the debate over Iraq's future. Most important among his public recommendations is his book What We Owe Iraq, in which he explores the ethical dilemmas of the occupation as well as his experience with the CPA and what he believes is the best way forward for the United States in Iraq (Fieldman, 2004). With regard to leaving behind a lasting democracy, Feldman casts the problem as a need to convince Iraq's Sunnis, specifically the insurgency, that it is in their best interests to lay down their arms and join the Shi'a and Kurds in a power-sharing arrangement. For him, this task is not simply a propaganda campaign; rather, it is necessary because it reflects reality. Because he asserts that "no power association in the country could reasonably believe that it alone would be able to govern the country and dominate everybody else." (Fieldman, 2004, p. 47) He believes that "democracy, then, was not merely the best political 
arrangement that could work in contemporary Iraq. Once it was realized that no single player could create an effective tyranny, democracy was also the only option other than chaos."

Following Saddam Hussein's ouster, he says, the Sunnis believed that they may still have had a chance of sabotaging the effort to establish constitutional democracy, and that they may still have been able to regain some semblance of their formerly dominant position in the old regime. In the formal terms favored by the game theorists who model democratization, some nontrivial number of Sunnis seemed to believe that the summed costs and benefits to them of subverting the emergence of a democratic government in Iraq outweighed the costs and benefits of entering into a democratic state in which they feared becoming permanent losers (Fieldman, 2004, p. 43). In saying this, Feldman does not mean that the Sunnis believed they had any realistic hope of reasserting the kind of dominance they enjoyed with Saddam in power. Rather, he claims that they feared that their weak demographic situation in relation to the Shi'a and Kurds, who had suffered mightily under the Sunni Ba'athist regime, would spell disaster for them in a democratic government. Therefore, both in order to avoid retribution and in order to retain as much of their former privileges as possible, they chose to fight the formation of a democratic system. The strategies of the Sunni insurgent groups, as Feldman describes, varied, but they shared two goals: to stall the establishment of constitutional democracy as long as possible, and to signal their willingness to resist oppression. The most prevalent strategy to achieve the first goal, according to Feldman, was the following: by killing Iraqi police and disrupting the possibilities of transition, the insurgents might be able to delay the emergence of a state with the power to enforce the laws. They could delay that process long enough for the United States to run out of patience and decide it was too costly to remain as an occupier. This scenario would also result in eventual American withdrawal, opening the door for the Sunnis to reassert control
(Fieldman, 2004). Feldman adds, "some Sunnis even believed that long-term anarchy would be preferable to living under Shi'i domination. (Fieldman, 2004)" Feldman writes, "One reason for the Sunni insurgency during the occupation was that Sunnis wanted to convince the Shi'a and the Kurds that oppressing them simply denying them a full share of state resources would be very costly. (Fieldman, 2004, p. 44)"

Seeing the conflict in Iraq through this rationalist lens, the solution to the problem appears simple-to convince the parties involved that democracy and sharing power is in their best interests. For Feldman, the most important actors that need convincing are the Sunni insurgents: the great challenge for an elected Iraqi government in which Shi' is are the most numerous will be to assure Iraq's Sunnis that they will not be treated as they treated the Shi'a and the Kurds. To draw again on the game theorists, the Shi'a and the Kurds must convince the overwhelming majority of Sunnis that their interests will be better served in a democratic government in which power will alternate than by continuing the insurgency to the point of civil war (Fieldman, 2004). While this solution seems simple, it is not. Reassuring a chronically insecure group that it has nothing to fear takes more than words-it requires guarantees. Feldman writes that the hardest part "will be to create institutions that will give Sunnis a reasonable hope of garnering a fair share of the spoils of electoral victory. (Fieldman, 2004, pp. 48-49)" He does not define what he means by a "fair share", but we can assume that he intends for Sunnis to feel comfortable that their voices will not be silenced by the Shi'a majority. This implies institutions that give Sunnis some sort of veto power, and also possible power-sharing arrangements that will guarantee them a role in the country's government. In this way, the Sunnis will see that joining the Kurds and Shi'a in a democratic union will be preferable to incurring the high costs of a continuing insurgency. 


\section{ON CONSTITUTIONAL ARRANGEMENTS}

A number of books and articles have been written with a primary concern of how to address the current ethnic conflict in Iraq and democratic transition of the country. Many of them are very pessimistic about such transition. Andres Schedler notes that "regime transition"...does not lead inevitably to democratic government. They represent risky journeys from authoritarianism "towards an uncertain something else" (Schedler, 2001). Even in the most favorable of circumstances, regime change is a decidedly hazardous undertaking and Iraq seems devoid of the most basic requirements for democracy, whatever view point is taken (Schedler, 2001). Therefore, as Dawisha argued democracy seems to be somewhat difficult to introduce into multi-ethnic-sectarian states emerging from the shadow of authoritarianism even in the best of circumstances (Dawisha, 2004). Andreas Wimmer ominously contends that 'the seeds of democracy may have difficulties to germinate in the sandy soils of Iraq' (Wimmer, 2003). He identified two contributing factors to that as follows: first, democracy is a government for the people and by the people, but Iraq was ethnically too heterogeneous to allow an obvious answer to the question 'who is the people? Secondly, and more importantly, no strong networks of civil society organizations have developed prior to democratization and introduction of the modern nation state (Wimmer, 2003, p. 113). Therefore, as he argued an important condition for consciationalism is missing. 'The centripetal drive will have to come from the outside', he argued, suggesting structural approaches to moderate ethnic claims and to have political positions converge at the center. Wimmer suggested a model similar to Nigeria's, where the most powerful official is elected not only by the majority of the population but also by a majority of states/ regions in the country; he also recommended the alternative-vote electoral system that requires parties to have branches in a minimum of provinces (Wimmer, 2003, pp. 111127). Meaning that a model- with electoral incentives for parties to appeal across ethnic or sectarian lines, devolution of power on territorial lines, and the establishment of a federal structure.

Khair El-Din Haseeb is one of the leading experts on Iraq and he has written extensively on Iraqi political system in post-Saddam Iraq. One of his edited books which deserves our attention addresses what was not previously addressed; namely Iraq's future and how it is being dealt with by Iraqi elites, which consisted of 108 scholars, all Iraqi of different disciplines of knowledge; the majority of them (66) live inside Iraq, the others outside of their homeland but in constant touch with Iraq's and Iraqi concerns, particularly those resulting from foreign occupation (Haseeb, 2006). Being a book on Iraq's future by Iraqis of knowledge and expertise is its main strength, it contains all revised papers and recommendations of a seminar organized by the Centre for Arab Unity Studies, one of the most prominent think tank in the Arab World. The seminar was financed mostly by its participants.

The plan and papers presented to the Seminar were the outcome of various working groups entrusted by the Center for Arab Unity Studies (CAUS) during 2005 to prepare such a plan for the post-liberated Iraq. Papers presented at the seminar were of two types: first, political and legal papers that define legislative framework to the political system to be installed in the liberated Iraq; second, policy-oriented academic researches that dealt with political, economic and military issues related to the Iraqi State and society, and its post-occupation future. The first group of papers presented a «Draft Constitution of the Republic of Iraq Post-Liberation»; Draft Law of Political Parties and Draft Law of General Election; and Draft Law of a High Commission for Election. The second dealt with the Reconstruction of the PostLiberation Iraq, the Oil Industry and Policy; the Rebuilding of the Iraqi Army; Media; Reparations Imposed on Iraq by the Security Council and their Impact; and the Kurdish Question. These papers, of both types, were debated in detail at the seminar by ad hoc committees, as well as at plenary sessions. The objective was, in both cases, providing basic constitutional and legal documents to rely on as guide-lines for 
the reconstruction of the Iraqi State and its political system, both destroyed by the U.S. invasion and occupation, and to reestablish both institutions on foundations of democracy. All in all these presentations aimed at providing Iraqis with a vision of the future, and an agenda for the rebuilding of their country. The book also includes the full text of a proposal for an American exit strategy launched in, the form of an initiative in consultation with active Iraqi political forces opposing occupation. It is a «Road Map» for the liberation of Iraq (Haseeb, 2006, p. 229).

The literature reviewed above on the post-Saddam political system deals largely with the role of the United States and the coalition forces in establishing and stabilizing the country's political system and its proper functioning. However, works referring to the institutions, processes and procedures of the political system are very few. There are occasional references to Iraqi politics, but there are no many in-depth studies providing an analysis of the nature of the political system and its expected outcomes. The few works in the area do not differentiate between the three dominant ethnic groups and their concerns vis-à-vis the country's internal organization and its future. Placing them in the same box as is often done is tantamount to equalizing centrifugal and centripetal forces, ignoring current history and obstructions created by colonial power.

Furthermore, the existing literature did not give much space to the domestic political elites and their interaction in running the affairs of the political system. Consequently, many pertinent questions relating to the government and politics of Iraq have remained unanswered. This study will attempt to fill in the gap in the literature and thus provide a comprehensive picture of the workings of the political system in the post-Saddam era. 